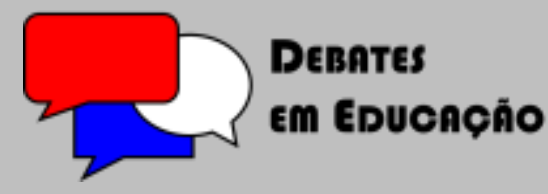

ISSN: 2175-6600

Vol. 9 | №. 18 | Mai./Ago. | Ano 2017

\section{Angela Maria Baltieri Souza}

Pontifícia Universidade Católica de São Paulo (PUC/SP)

angelamariabaltieri@gmail.com

\section{Clarilza Prado de Sousa}

Pontifícia Universidade Católica de São Paulo

(PUC/SP)

clarilza.prado@uol.com.br

\title{
O AGIR POR MEIO DA LINGUAGEM: GÊNERO MEMÓRIAS LITERÁRIAS
}

\section{RESUMO}

O texto discute produções textuais do gênero Memórias Literárias de alunos/autores e finalistas da Olimpíada de Língua Portuguesa Escrevendo o Futuro - 2014. Objetivou-se analisar a linguagem expressa em uma situação de comunicação real, identificar como esses autores descrevem e estão sendo orientados a discutir o lugar em que vivem, incluindo também a sua própria experiência. Por meio de referencial teórico postulado pela Teoria das Representações Sociais e do Interacionismo Sociodiscursivo, o estudo permitiu analisar a voz do sujeito (aluno), suas relações interpessoais/marcas de convivência (relação eu /outro / mundo / nós / família / comunidade) no texto, considerando conjuntamente os processos para chegar à produção textual. O software ALCESTE apoiou a análise dos textos que partiu de um corpus composto por 38 produções textuais (autorais) escritas em interações sociais do gênero Memórias Literárias. Os resultados permitiram observar que ao escrever o seu texto, o aluno/autor traz elementos do passado do outro, valorização dos sentimentos da época e descrição do tempo para falar do lugar onde vive. Esse passado do outro, produzido a partir da mediação do professor, revela a priorização do texto do sujeito/autor para descrever o lugar em que vive (agir e representar) por meio de uso do gênero textual Memórias Literárias.

Palavras-chave: Formação do leitor. Mediação. Didática. Política.

\section{ACTING THROUGH LANGUAGE: GENDER LITERARY MEMORIES}

\begin{abstract}
The text discusses textual productions of the genre Literary Memories of students / authors and finalists of the Portuguese Language Olympiad Writing the Future - 2014. The objective was to analyze the language expressed in a real communication situation, to identify how these authors describe and are being oriented to discuss where they live, including their own experience. By means of a theoretical reference postulated by the Theory of Social Representations and Sociodiscursive Interactionism, the study allowed to analyze the subject's voice (student), their interpersonal relations / coexistence marks (relation I / other / world / us / family / community) in the Text, considering together the processes to arrive at textual production. The software ALCESTE supported the analysis of the texts that originated from a corpus composed of 38 textual productions (authored) written in social interactions of the genre Literary Memories. The results allowed us to observe that in writing his text, the student / author brings elements of the other's past, valuing the feelings of the time and describing the time to talk about where he lives. This past from the other, produced from the teacher's mediation, reveals the prioritization of the subject / author's text to describe the place in which he lives (acting and representing) through the use of the textual genre Literary Memories.
\end{abstract}

Keywords: Discourse genres. Social Interactionism. Social Representations. 


\section{INTRODUÇÃO}

A utilização de diversos gêneros textuais como instrumentos para o processo de ensino-aprendizagem visa o desenvolvimento da dialogicidade "[...] que gera os tipos diversos de pensamento e de comunicação" (MARKOVÁ, 2006, p.128). Ainda a apoiar esse tipo de estratégia do ensino, estariam as observações da autora:

A história e a cultura impõem demandas nos estilos dialógicos de pensamento e comunicação e os restringem em direções específicas. Por exemplo, existem tipos diferentes de restrições do passado e do presente [...]. Como também a enorme variedade de situações nas quais o pensamento e a comunicação acontecem, resultam na característica essencial da dialogicidade: sua natureza multifacetada, multivocal e polifásica (MARKOVÁ, 2006, p.136).

Assim, ao basear-se nessas proposições o presente texto pretende discutir como como a linguagem expressa pela atividade linguística, produzida em uma situação de comunicação real, identifica como esses autores descrevem e discutem o lugar em que vivem, incluindo também a sua própria experiência de vida.

Parte-se dos resultados obtidos de estudo realizado junto a produções textuais do gênero Memórias Literárias de alunos/autores e finalistas da Olimpíada de Língua Portuguesa Escrevendo o Futuro - 2014. Relata-se os resultados de análise de textos produzidos por esses alunos em situação de comunicação real (gênero Memórias Literárias).

Apresenta-se essas análises procurando compreender como a voz do sujeito e suas relações interpessoais/marcas de convivência (relação eu/outro analisar mundo/nós/família/comunidade) se revelam em um texto e, sobretudo, como processos de ensino interferem na interação entre o eu e o outro, eu e o mundo e engloba diferentes formas de pensar, que são refletidas por meio de linguagem.

O gênero Memórias Literárias foi abordado nesse estudo com o tema "O lugar onde vivo". A produção escrita dos textos foi desenvolvida com a mediação do professor de Língua Portuguesa, que instrumentalizou a aprendizagem por meio dos gêneros (orais e escritos). Esse processo de ensino envolveu a realização de uma sequência de atividades orais e escritas, em um processo de ensino que compreendeu a realização de uma entrevista com um morador antigo do lugar em que o aluno vive e trabalho em classe para discussão das entrevistas e de transposição da linguagem oral para a escrita, bem como, a utilização de estratégias de leitura e escrita em diversos gêneros, para alimentação temática e para o desenvolvimento da produção textual. 
Os instrumentos de ensino utilizados pelo professor de Língua Portuguesa compõem a sequência didática para a produção do texto, que estão consubstanciadas no caderno do professor Se bem me lembro... (CENPEC, 2010). Na seção logo a seguir sobre o título Breve histórico sobre a Olimpíada de Língua Portuguesa, com um breve resumo do caminho percorrido para que o aluno chegue à autoria do texto final.

Tomando os textos produzidos pelos alunos, após esse processo didático, procurouse analisar como diferentes modos de pensamento contribuem para a desvelar as pistas do agir do sujeito e de suas representações.

Ao selecionar as produções textuais de sujeitos com a temática "O lugar onde vivo", procurou-se compreender os vínculos que traziam com a comunidade, aprofundar 0 conhecimento sobre o lugar onde os alunos vivem e sobre as relações que se estabelecem na convivência humana.

A investigação apoiou-se no estudo de gêneros textuais de Joaquim Dolz e Bernard Schneuwly e no Interacionismo Sociodiscursivo (ISD), adotando-se a perspectiva de Jean Paul Bronckart. Esse viés abrange uma análise linguístico-discursiva do texto do aluno, sobre o emissor/enunciador, o receptor/destinatário, a instituição social onde se dá a interação e o objetivo ou efeitos que o produtor quer atingir em relação ao destinatário.

Procurando, também, conhecer e tecer pistas expressas na linguagem escrita (gênero Memórias Literárias), que revelam os sentidos e significados que os alunos atribuíram ao "lugar onde vivem", procurou-se analisar as representações sociais presentes nos textos, utilizando o aporte teórico de Serge Moscovici e Ivana Marková sobre a Teoria das Representações Sociais (TRS).

O ISD é considerado uma vertente da psicologia da linguagem, que estuda "a ciência do humano". Surgiu e foi desenvolvido na Unidade de Didática de Línguas ${ }^{1}$ da Universidade de Genebra e fazem parte dessa vertente os trabalhos desenvolvidos sobre a questão do ensino-aprendizagem de gêneros textuais (SCHNEUWLY, 1994; SCHNEUWLY e DOLZ, 2004 apud MACHADO e LOUSADA, 2010, p.621) e trabalho educacional (BRONCKART, 1997, 2004, 2008 apud op. cit.). Ao constituir-se como ciências sociais humanas, o ISD aborda questões de ordem filosófica, psicológica, linguística e didática de forma transdisciplinar. Segundo Bronckart (2006), essa abordagem decorre de três princípios fundadores do Interacionismo Social do começo do século XX:

\footnotetext{
1 Unidade de Didática de Línguas - nomenclatura utilizada por Jean-Paul Bronckart, é compatível à linguística aplicada, citado por Machado (2004, p. 324).
} 
- de um princípio de Mead, segundo o qual o desenvolvimento do social (a elaboração dos fatos sociais e os mecanismos de socialização) e o desenvolvimento psicológico das pessoas são duas facetas de um único e mesmo processo;

- e de dois princípios de Vygotsky: o princípio de que não se pode trabalhar seriamente em ciências humanas sem clarificar sua posição epistemológica e seu questionamento, o que implica levar em consideração a parte do "corpus" filosófico que se centra nas questões do espírito, do social e da ação; e, em segundo lugar, o princípio de que a atividade prática é um objeto central de qualquer ciência do humano e que, consequentemente, essa ciência deve buscar teorizar as práticas, ao mesmo tempo em que intervém nessas práticas (em particular, no quadro da educação e da formação) (MACHADO, 2004, p. 321).

Ao considerar a "[...] atividade linguareira como um aspecto fundamental de toda prática social ou individual”, Bronckart (2006), pondera, assim como, sustentava Saussure, que se trata ao mesmo tempo, "dos aspectos sociais, linguareiros, psicológicos e educacionais" (op. cit.), articulados aos "[...] processos que operam no desenvolvimento (histórico) humano", que se decompõe em:

- Como caracterizar as propriedades universais das atividades linguageiras (enquanto textos e discursos produzidos no quadro de uma língua natural)?

- Que papel desempenha a maestria dessas atividades linguageiras nas formas de elaboração dos conhecimentos (tipos de raciocínio) e na formação de unidades de ação?

- Como os processos linguageiros mencionados podem gerar regras e normas que se cristalizam em instituições sociais e podem dar origem ao pensamento consciente humano?

- Em que e em quais condições, a atividade de trabalho e sua análise podem contribuir para o desenvolvimento e a formação das pessoas que trabalham? (MACHADO, 2004, p.322).

O ISD procura evidenciar que as práticas de linguagem situadas (textos/discursos) são instrumentos para o desenvolvimento de saberes e agir das pessoas.

A TRS foi desenvolvida por Moscovici que a considera como uma teoria que pretende discutir um fenômeno que se constitui na comunicação e se expressa pelos diferentes tipos de linguagem. As representações sociais como afirmou Moscovici (1961, 1976 apud MARKOVÁ, 2006, p.274) podem transmitir representações e emoções, que vão além "do significado semântico".

Segundo Moscovici (2015, p.35), “[...] nós organizamos nossos pensamentos, de acordo com um sistema que está condicionado, tanto por nossas representações, como por nossa cultura". Nesse sentido, para Marková as representações sociais:

[...] são "produtos que incluem um senso comum pré-reflexivo, bem como, várias formas de conhecimentos e crenças pré-reflexivos e reflexões socialmente partilhadas, bem como experiências de realidade, rotinas, crises de vida e tipos habituais de conhecimento. [...] pré-reflexivos e reflexivos como também relativamente estabilizados e incontroversos, bem como também relativamente 
estabilizados e incontroversos e argumentativos. [...] estes tipos de conhecimento e crenças são características de representações e da representação social (MARKOVÁ, 2015, p.95-96 apud JESUÍNO).

Para tanto, Moscovici elegeu a articulação entre o pensamento e a linguagem como "[...] representação social, baseada no pensamento de senso comum, no conhecimento e na comunicação (MOSCOVICI, 2015, p.188). Afirma que os componentes da "tríade dialógica" (Alter-Ego-Objeto) são "internamente relacionados" por meio de "gestos verbais e não verbais", assim, "[...] as atividades que fazem sentido estão orientadas em relação ao passado e em relação às interpretações retrospectivas, podendo antecipar quais as direções que o conhecimento e a comunicação podem adotar" (ibid., p. 188, 212-215).

Marková (2015), portanto, afirma, que os "gêneros de comportamento", bem como, os "gêneros de comunicação, são fatos do ambiente social (convencionais e institucionais). Dando uma orientação dupla entre o "pensamento" e a "linguagem". (ibid., p.269-270) Pois "o senso comum é socialmente partilhado, mas não reflexivo", com a presença de normas pré-estabelecidas na sociedade (morais, legais, éticas aceitas socialmente, etc.), que são transmitidas de "geração em geração através da linguagem e da comunicação". Entretanto, para haver um pensamento dialógico precisa ser refletido, por meio de mecanismos psicológicos, no consenso grupal. (id., 2015, p. 93-94 in JESUÍNO)

Moscovici, considera a representação social como "[...] uma modalidade específica de conhecimento, que tem por função a elaboração de comportamentos e a comunicação entre os indivíduos", no quadro da vida cotidiana (MOSCOVICI, 1948ª , 1984c, 1989 apud SÁ, 2015, p.187).

Significa que o sujeito que produz sistemas simbólicos e sociais na construção da realidade é construtor da realidade e também é construído pela realidade social.

O autor postula que "[...] conjuntos de conceitos, afirmações, conhecimentos e saberes", que são as representações sociais, devem ser consideradas como verdadeiras "teorias" do senso comum, "ciências coletivas" sui generis, pelas quais se procede à interpretação e mesmo à construção das realidades sociais (MOSCOVICI, 1976, p.48 apud ibid., p.189-190). Para ele "as representações sociais, por seu poder convencional e prescritivo sobre a realidade, terminam por constituir o pensamento em um verdadeiro ambiente onde se desenvolve a vida cotidiana", que faz parte da vida em sociedade. Essa representação ocorre por uma tensão entre o indivíduo e o grupo, na "comunicação que se estabelece entre o conceito e a percepção, um penetrando no outro". (SÁ 1976, p. 56-57 apud ibid., p.197).

Marková (2006, p.128), analisando o processo de comunicação introduz a questão da antinomia Alter-Ego como a "hipóteses da dialogicidade". E dialogicidade como afirma a 
autora, é a "[...] capacidade fundamental da mente humana em conceber, criar e comunicar sobre realidades sociais". E prossegue a autora o Alter-Ego é "uma ontologia da comunicação e, por implicação, uma ontologia da mente humana, então é a dialogicidade que gera os tipos diversos de pensamento e de comunicação".

É, portanto, o pensamento expresso pela linguagem quando concebe o mundo e cria realidades sociais (indivíduo e o grupo). Assim, para a autora (ibid., p. 139) a dialogicidade preocupa-se com a existência humana (existência comunicativa), visto que os participantes "dialógicos entendem ativamente as mensagens dos outros, qualquer elocução já carrega um germe de uma resposta". (VOLOSHINOV, 1929, 1973; ROMMETVEIT, 1974 apud ibid., p.148). Quando um participante dialógico usa recursos comunicativos públicos e compartilhados é capaz de "sincronizar seus significados, no tempo e no espaço, para que possam transmiti-los e torná-los parte do conteúdo da mensagem" (MARKOVÁ, 2006, p.155).

Essas duas linhas teóricas foram utilizadas no estudo, de um lado a ISD e, de outro a TRS, postulam abordagem transdisciplinar das ciências humanas/sociais, sendo possível obter uma visão da atividade em que o sujeito produziu linguagem e das contingências do contexto que definiram esse tipo de produção. É por meio da comunicação que o sujeito constrói o conhecimento linguístico que é transmitido de geração em geração e que o expressa através de linguagem verbal e não verbal. O texto dos alunos construído na cotidianidade está orientado por representações sociais que esse o aluno tem sobre os objetos e as coisas.

Assim, a compreensão dessas representações expressas e construídas na comunicação estabelecem segundo Marková "as relações de Alter-Ego-Objeto", que são éticas (avaliativas e críticas) e que, portanto, permitem identificar as crenças e valores dos sujeitos envolvidos no processo (id., 2015, p.94 In JESUíNO).

\section{BREVE HISTÓRICO SOBRE A OLIMPÍADA DE LÍNGUA PORTUGUESA (OLP)}

A OLP é um concurso de texto, promovido em parceria entre o Ministério da Educação (MEC) e a Fundação Itaú Social, sob a coordenação técnica do Centro de Estudos e Pesquisas em Educação, Cultura e Ação Comunitária (CENPEC), que busca democratizar o ensino de Língua na escola pública, quanto ao desenvolvimento interativo, textual, gramatical e do ponto de vista social da língua. 
Ao participar da OLP o professor de Língua Portuguesa recebe orientações que estão apresentadas no Caderno do Professor, o qual contém uma proposta didática referente ao gênero escolhido para trabalhar junto com o aluno (Poema, Memórias Literárias, Crônica ou Artigo de opinião). O material estimula a vivência do professor à metodologia de ensino por meio de gêneros textuais e ISD.

Em relação ao aluno, visa-se a apropriação ou aprimoramento da linguagem escrita, ao mobilizar jovens e crianças para o desenvolvimento da língua materna em situações de uso como da família, da escola, do mundo do trabalho.

Participam do concurso em anos pares professores de todo o Brasil (por adesão), juntamente com seus respectivos alunos do $5^{\circ}$ ano do Ensino Fundamental (EF) à 3a série do Ensino Médio (EM) e nas seguintes categorias Poema (5ํe 6ํanos EF); Memórias

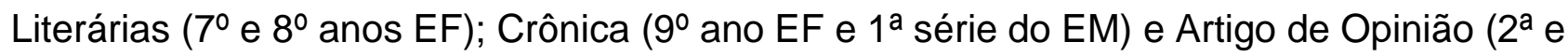
$3^{\text {a }}$ séries do EM).

A OLP vai além de um concurso de texto, pois oferece propostas de formação ao docente para refletir sobre as práticas educativas, que acontece em anos ímpares. Essa formação ocorre (online) em ambiente virtual de aprendizagem, por meio de cursos gratuitos oferecidos aos docentes, como por exemplo, Sequência didática: aprendendo por meio de resenhas; Caminhos da Escrita; Leitura vai, escrita vem: práticas em sala de aula.

Há, também, uma comunidade de aprendizagem² no site $^{3}$ da OLP voltada ao ensino da Língua Portuguesa, que reúne textos dos alunos finalistas dos anos anteriores, entrevistas com especialistas, práticas de sala de aula, relatos de prática das oficinas presenciais realizadas na etapa de escolha dos textos finalistas.

Para o processo de seleção dos textos são realizadas comissões julgadoras compostas por professores em todas as etapas de escolha (escolar, municipal, estadual e regional) por meio de utilização de critérios constantes da grade de correção que perpassa todas as etapas do processo de produção do gênero Memórias Literárias, o qual se explicita na próxima seção.

O processo de seleção é realizado inicialmente na escola, quando se seleciona o texto finalista da escola, entregue à comissão Municipal de Educação, responsável pela próxima fase do concurso, recebe os textos escolhidos nas escolas (online).

Após essa etapa (escolar), é formada a comissão julgadora municipal, composta por professores de Língua Portuguesa e um especialista de universidade pública, responsáveis pela seleção dos textos que representarão o município na próxima fase (etapa estadual).

\footnotetext{
2 Disponível em:<https://www.escrevendoofuturo.org.br/percursos $>$. Acesso em: 30 de maio de 2017.

${ }^{3}$ Disponível em:<https://www.escrevendoofuturo.org.br/>. Acesso em: 30 de maio de 2017.
} 
Os autores dos textos (os alunos) selecionados, assim como seus professores orientadores participarão da etapa regional, em que terão oportunidade de aperfeiçoarem suas produções escritas.

Nessa etapa, a comissão julgadora (composta por especialistas) realiza oficinas com os alunos e seus respectivos professores, em um período de 3 dias. O professor recebe orientação de especialistas em oficinas coletivas, que apresentam o panorama geral sobre a escrita dos 500 textos e, de como o processo de reescrita, poderia ajudar a melhorá-los. Após a reflexão, o docente orienta seu aluno para que ele reescreva seu texto. O propósito desse processo é que ao apropriar-se de conceitos, metodologias e princípios, o docente possa refletir sobre a sua atividade, favorecendo a aprendizagem e o desenvolvimento dos alunos quando voltarem para suas escolas.

As oficinas com os alunos permitem a vivência de atividades escritas e orais para desenvolver e checar a autoria, permitindo uma análise crítica e técnica durante o processo de seleção dos textos. Finalmente, os classificados seguem para a última fase do concurso, que ocorre em nível nacional com a participação de especialistas.

O propósito desse processo é que ao apropriar-se de conceitos, metodologias e princípios, o docente possa refletir sobre a sua atividade, propiciando a aprendizagem e o desenvolvimento dos alunos quando voltarem para suas escolas.

\subsection{Como o aluno chega à produção?}

O desenvolvimento da produção textual permeia um processo de ensinoaprendizagem apoiado por uma sequência didática (SD), ou seja, um conjunto de atividades progressivas e planificadas para "melhorar determinada prática de linguagem". A SD instaura uma "primeira relação entre um projeto de apropriação de uma prática de linguagem e os instrumentos que facilitam essa apropriação" (DOLZ; SCHNEUWLY, 2011, p. 43).

Para tanto, a produção textual é desenvolvida ao longo de 16 oficinas, todas elas voltadas para a compreensão do contexto de produção o que, também, contribui para o desenvolvimento da capacidade de ação sobre a linguagem. Desse modo, o professor trabalha com todos os alunos de sua classe, desenvolvendo e adequando a SD conforme a necessidade dos alunos. Ao término de cada oficina o professor faz o registro das aulas para aperfeiçoar o seu trabalho e reflete sobre sua prática.

A seguir apresenta-se em formato de tabela o desenvolvimento da SD (gênero Memórias Literárias), descreve-se o título de cada oficina e os seus objetivos: 
Tabela 1 - Caderno do Professor: Se bem me lembro...

\begin{tabular}{|c|c|c|}
\hline \multicolumn{3}{|c|}{$\begin{array}{c}\text { Apresentação das oficinas para a produção do gênero Memórias Literárias - segundo o } \\
\text { caderno do professor Se bem me lembro... }\end{array}$} \\
\hline Oficina & Título da oficina & \begin{tabular}{|c|} 
Objetivos \\
\end{tabular} \\
\hline 1 & Naquele tempo... & $\begin{array}{l}\text { - Valorizar a experiência das pessoas; } \\
\text { - Compreender o que é memória; } \\
\text { - Perceber como objetos e imagens podem trazer lembranças } \\
\text { de um tempo passado; } \\
\text { - Observar que as memórias podem ser registradas oralmente } \\
\text { ou por escrito. }\end{array}$ \\
\hline 2 & Vamos combinar? & $\begin{array}{l}\text { - Conhecer a situação de comunicação de textos de } \\
\text { Memórias Literárias. }\end{array}$ \\
\hline 3 & $\begin{array}{l}\text { Semelhantes, porém } \\
\text { diferentes }\end{array}$ & $\begin{array}{l}\text { - Conhecer gêneros que se assemelham por terem como } \\
\text { principal ponto de partida experiências vividas pelo autor; } \\
\text { - Orientar o aluno a identificar as principais características do } \\
\text { texto que ele deverá escrever. }\end{array}$ \\
\hline 4 & ras linhas & - Produzir o primeiro texto de Memórias Literárias. \\
\hline 5 & $\begin{array}{l}\text { Tecendo fios da } \\
\text { memória }\end{array}$ & $\begin{array}{l}\text { - Explorar o plano global do texto de Memórias Literárias; } \\
\text { - Observar o foco narrativo presente em boa parte desses } \\
\text { textos. }\end{array}$ \\
\hline 6 & $\begin{array}{l}\text { Lugares que moram } \\
\text { na gente }\end{array}$ & $\begin{array}{l}\text { - Perceber as diferentes características da descrição em } \\
\text { textos de Memórias Literárias; } \\
\text { - Observar o efeito provocado pela forma como o autor } \\
\text { descreve os fatos, sentimentos e sensações nesse gênero de } \\
\text { texto. }\end{array}$ \\
\hline 7 & $\begin{array}{l}\text { Nem sempre foi } \\
\text { assim }\end{array}$ & $\begin{array}{l}\text { - Observar como os autores comparam o tempo antigo com o } \\
\text { atual. }\end{array}$ \\
\hline 8 & $\begin{array}{l}\text { Na memória de } \\
\text { todos nós }\end{array}$ & $\begin{array}{l}\text { - Analisar marcas linguísticas presentes em textos de } \\
\text { Memórias Literárias. }\end{array}$ \\
\hline 9 & Marcas do passado & $\begin{array}{l}\text { - Observar o uso do pretérito perfeito e do imperfeito em } \\
\text { textos de Memórias Literárias; } \\
\text { - Relembrar usos e flexões dos tempos verbais; } \\
\text { - Identificar palavras e expressões usadas para remeter ao } \\
\text { passado. }\end{array}$ \\
\hline 10 & Ponto a ponto & $\begin{array}{l}\text { - Observar o uso de sinais de pontuação em textos de } \\
\text { Memórias Literárias. }\end{array}$ \\
\hline 11 & sta & - Planejar e realizar entrevistas. \\
\hline 12 & $\begin{array}{l}\text { Da entrevista ao } \\
\text { texto de Memórias } \\
\text { Literárias }\end{array}$ & $\begin{array}{l}\text { - Analisar, juntamente com os alunos, os procedimentos } \\
\text { realizados para a transformação de um trecho de entrevista } \\
\text { em fragmento de Memórias Literárias (retextualização). }\end{array}$ \\
\hline 13 & Como num filme & $\begin{array}{l}\text { - Analisar um texto de Memórias Literárias produzido em } \\
\text { situação semelhante àquela que será proposta aos alunos; } \\
\text { - Observar como o autor organiza as vozes presentes no } \\
\text { texto. }\end{array}$ \\
\hline 14 & saio geral & - Produzir um texto coletivo. \\
\hline 15 & gora é a sua vez & - Escrever individualmente a primeira versão do texto final. \\
\hline 16 & Últimos retoques & $\begin{array}{l}\text { - Fazer a revisão e o aprimoramento do texto produzido na } \\
\text { oficina anterior. }\end{array}$ \\
\hline
\end{tabular}

Fonte: Clara, Altenfelder e Amanda (2010).

A seguir elenca-se os critérios de avaliação da OLP, descritos em formato de uma grade de correção, que compõem os elementos necessários para o desenvolvimento da escrita do gênero. Esses critérios também são utilizados nas comissões julgadoras.

Tabela 2 - Grade de Correção OLP 


\begin{tabular}{|c|c|c|}
\hline \multirow[b]{2}{*}{ CRITERIOS } & \multirow[b]{2}{*}{ PONTUAÇÃ̃o } & EMORIAS LIIERARIAS \\
\hline & & DESCRITORES \\
\hline $\begin{array}{l}\text { Terna "O lugar } \\
\text { onde vivo" }\end{array}$ & 1,5 & $\begin{array}{l}\text {-0 toxto se reporta de forma pertinentr à cultura } \\
\text { ea história do lugar onde vivem? }\end{array}$ \\
\hline \multirow{11}{*}{$\begin{array}{l}\text { Adequaçào } \\
\text { ao gênero }\end{array}$} & \multirow{5}{*}{2.0} & Adequaçáo discursiva \\
\hline & & - O texto resgata aspectos do lugar onde vivem \\
\hline & & $\begin{array}{l}\text { - } 0 \text { texto deixa transparecer sentimentos, impressoes } \\
\text { apreciaçòes que atendern à finalidade de enredar o leitor? }\end{array}$ \\
\hline & & $\begin{array}{l}\text {-A organizaça geral do texto obedece à logica interna } \\
\text { da narrativa? }\end{array}$ \\
\hline & & $\begin{array}{l}\text { - As referencias a objetos lugares modos de vida, costumes, } \\
\text { palavras e expressốes que já não existem ou se } \\
\text { transformaram reconstroem experiēncias pessoais vividas? }\end{array}$ \\
\hline & \multirow{5}{*}{2,0} & Adequaçắo linguistica \\
\hline & & -As memórias sao assumidas en primeira pessoa? \\
\hline & & $\begin{array}{l}\text { - No caso de o autor recorrer a cutras vozes estão } \\
\text { adequadamente articuladas no texto? }\end{array}$ \\
\hline & & $\begin{array}{l}\text { - } 0 \text { uso dos tempos verbais e dos indicadores de espaço } \\
\text { situa adequadamente o leitor em relaçào aos tempos } \\
\text { e espaços retratados no texto? }\end{array}$ \\
\hline & & $\begin{array}{l}\text { - Os recursos de linguagem şo adequados ao caráter } \\
\text { literario das memárias? }\end{array}$ \\
\hline & 1,0 & $\begin{array}{l}\text { - } 0 \text { texto deixa transparecer que o autor fez entrevistas } \\
\text { para produzi-lo, recuperando lembranças de outros } \\
\text { tempos relacionadas ao lugar onde vive? }\end{array}$ \\
\hline \multirow{2}{*}{$\begin{array}{l}\text { Marcas de } \\
\text { autoria }\end{array}$} & \multirow[b]{2}{*}{2,0} & . 0 titulo instiga o leitor? \\
\hline & & $\begin{array}{l}\text { - } 0 \text { autor elaborou de modo próprio e original as } \\
\text { lembrancas dos moradores entrevistados? }\end{array}$ \\
\hline \multirow{2}{*}{$\begin{array}{l}\text { Convenções } \\
\text { da escrita }\end{array}$} & \multirow[b]{2}{*}{1,5} & $\begin{array}{l}\text { - O texto atende ás convençôes da escrita (morfossintaxe, } \\
\text { ortografia, acentuaçăa, pontuaçâa)? }\end{array}$ \\
\hline & & $\begin{array}{l}\text { - Quando há rompimento das convencobes da escrita, } \\
\text { isso ocorre a servip̧o do sentido do texto? }\end{array}$ \\
\hline
\end{tabular}

Fonte: Clara e Altenfelder (2010, p. 149).

Pode-se afirmar, que ao final do processo de escrita e aprimoramento do texto, é possível destacar o nível de socialização do aluno/autor em relação ao lugar em que vive (comunidade, escola e família), a partir das marcas presentes em seu texto, sua forma de interação (texto escrito) com o mundo (o outro).

\section{A PESQUISA}

A pesquisa realizada consistiu primeiramente em selecionar os textos produzidos pelos alunos, orientados pela mediação do professor de Língua Portuguesa e sequência didática descrita na (OLP). 
O concurso foi promovido em parceria entre o Ministério da Educação (MEC) e a Fundação Itaú Social, sob a coordenação técnica do Centro de Estudos e Pesquisas em Educação, Cultura e Ação Comunitária (CENPEC), sendo selecionados para o estudo os textos dos alunos/autores e finalistas de 2014 - Gênero Memórias Literárias, selecionados na etapa regional por meio de critérios estabelecidos pela OLP.

Trata-se de um corpus com 38 textos de alunos entre 12 e 13 anos de ambos os sexos, matriculados nos $7^{\circ}$ e $8^{\circ}$ anos do Ensino Fundamental Anos Finais na Rede Pública de Ensino (Municipal e Estadual).

Dentre os textos finalistas de Memórias Literárias, há representação de 22 estados brasileiros, os quais estão descritos a seguir: Acre, Alagoas, Amazonas, Bahia, Ceará, Espírito Santo, Goiás, Maranhão, Mato Grosso, Mato Grosso do Sul, Minas Gerais, Paraíba, Paraná, Pernambuco, Piauí, Rio de Janeiro, Rio Grande do Norte, Rio Grande do Sul, Rondônia, Santa Catarina, São Paulo e Tocantins.

Posteriormente, o corpus foi submetido ao software ALCESTE (Analyse Lexicale par Contexte d'un Ensemble de SegmenT de texte) para quantificar a análise textual. $\mathrm{O}$ programa ALCESTE desenvolvido pelo francês Marx Reinert ${ }^{4}$ é usado no Brasil por pesquisadores das Ciências Humanas e segundo Camargo (2005, p.511) preserva o fenômeno estudado, permitindo a avaliação dos objetos com base na opinião dos sujeitos. O ALCESTE permite o trabalho com corpus variados (entrevistas, questionários abertos, obras literárias, propagandas, revistas, documentos extensos, etc.). Desse modo, ao quantificar os textos, que compõem o corpus o programa extrai as estruturas mais significativas.

Para a obtenção dos dados, organizou-se o corpus de acordo com as regras do ALCESTE (Análise Lexical Contextual de um Conjunto de Seguimentos de Texto). O arquivo foi preparado com a utilização de regras próprias para digitar os 38 textos ou Unidades de Contexto Inicial (U.C.I.). Cada (U.C.I.) é separada e identificada por uma linha com o sinal de $\left(^{* * *}\right)$, depois há a caracterização dos sujeitos da pesquisa (1 a 38) e as variáveis (sexo e estado), como pode-se observar no exemplo que segue:

**** *suj_001 *sex_2 *estado_33

O processamento do corpus monotemático no ALCESTE correspondeu a quatro etapas ( $A, B, C$ e D). Na primeira, há identificação das unidades de registro

\footnotetext{
${ }^{4}$ Disponível em:<http://www.ling.uqam.ca/forum/satoman/images/AlcesteNoticeSimplifiee.pdf $>$. Acesso em: 30 de maio de 2017.
} 
(identificação das palavras), com a leitura do texto e cálculo dos dicionários. Na segunda, identificação e seleção das Unidades de contexto Elementar (U.C.E), que contém as palavras significativas de uma classe. Na terceira, a definição de classes escolhidas, ilustradas por um dendrograma que esclarece a relação entre as classes. E na última, cálculos complementares (seleção da U.C.E.), ilustrados pela Classificação Hierárquica Ascendente (C.H.A.).

A partir do processamento do corpus, destacaram-se as palavras pelo grau de importância. Assim, por meio da valoração do qui-quadrado $\left(\mathrm{khi}^{2}\right)$, que representa a frequência dessas palavras no corpus, foram divididas as três classes, como observado a seguir:

Figura 1- dicionário com as palavras e valor do $\mathrm{khi}^{2}$

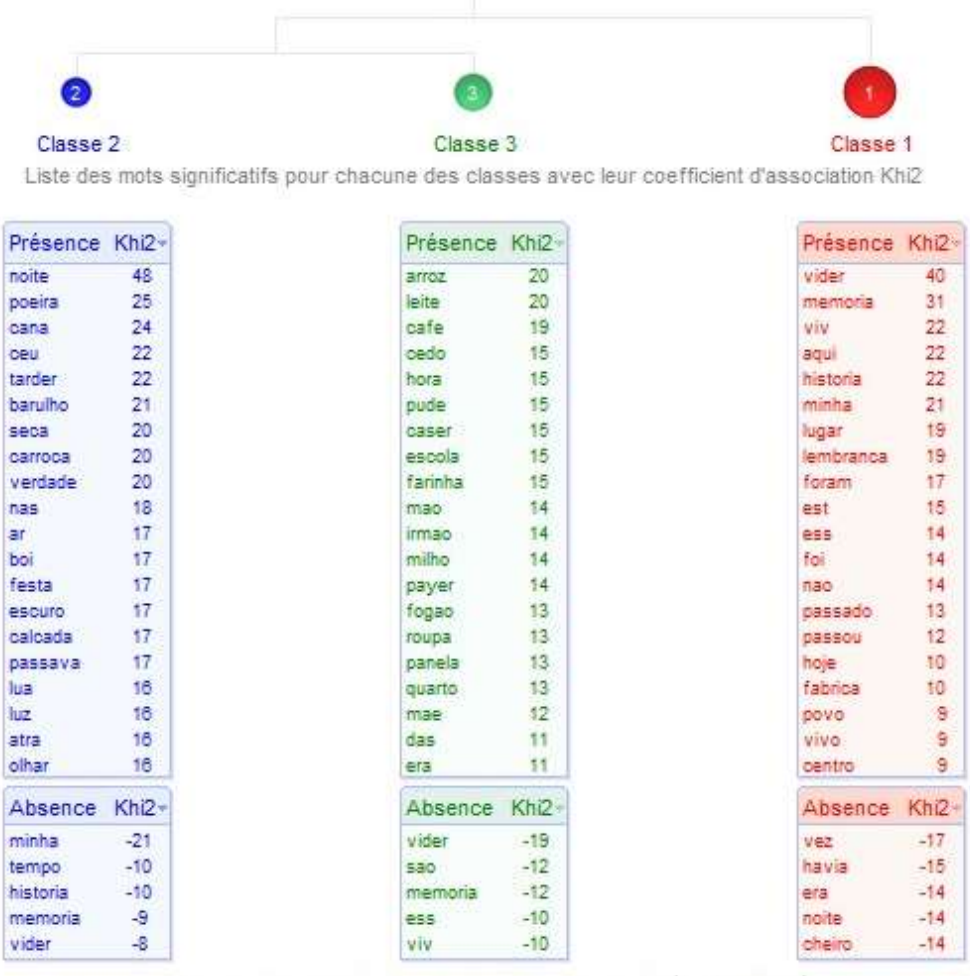

Fonte: ALCESTE (ano). 
Figura 2 - Dendrograma sobre a Classificação Hierárquica Descendente

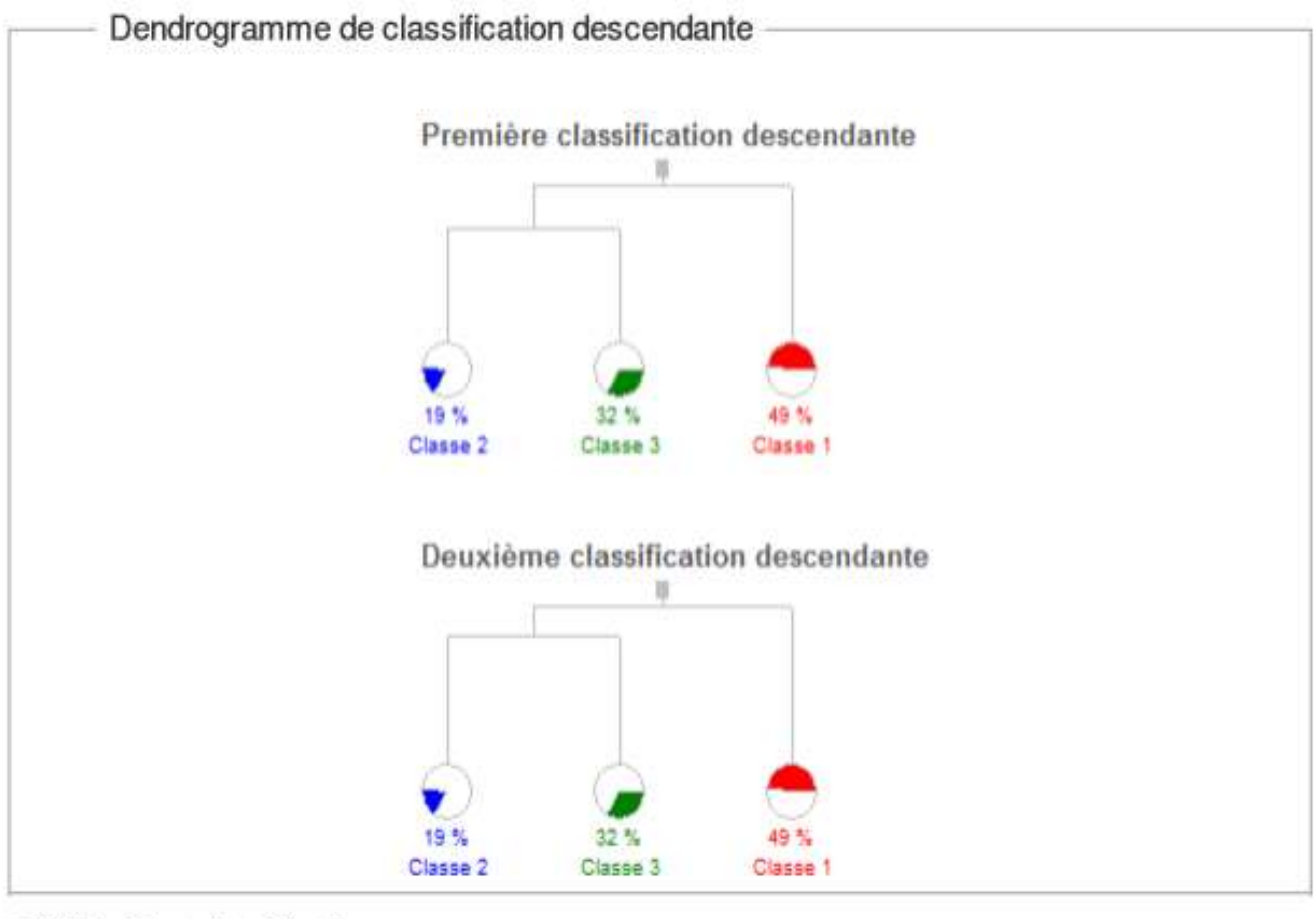

9 IMAGE - Alcosto Plus Education

Fonte: ALCESTE.

A partir dos resultados do ALCESTE, optou-se por analisar as palavras com maior grau de importância, desse modo, selecionou-se na pesquisa as palavras que obtiveram o maior khi² e de forma decrescente até o valor do khi 12 .

A seguir, apresenta-se as classes e suas respectivas palavras escolhidas de acordo com a valoração do $\left(\mathrm{khi}^{2}\right)$, analisadas semanticamente no contexto do trecho selecionado pelo ALCESTE.

Classe 1 - vida, viver e memória.

Classe 2 - noite, poeira, cana, tarde, céu, barulho, seca, carroça, ar, boi, festa, escuro, calçada, luz, olhar, quente, diversão, vento, corpo, foguete, correndo e começou.

Classe 3 - arroz, leite, milho e café.

É importante ressaltar que, a análise quantitativa do ALCESTE, é um facilitador utilizado pelo pesquisador para aprimorar seu olhar à luz do referencial teórico, já mencionado anteriormente. 


\section{DISCUSSÃO}

Em relação aos resultados processados pelo ALCESTE obteve-se especificação de $80 \%$ do corpus, o que é considerado um resultado relevante. Assim, ao processar o corpus (conjunto de 38 textos) produzido pelos sujeitos da pesquisa, verificou-se 3 classes e os respectivos valores do $\mathrm{Khi}^{2}$, que representam a força do sentido da palavra no discurso: classe $1(49 \%)$, classe 2 (19\%) e a classe $3(32 \%)$.

Por meio de análise semântica em relação às palavras das (classes 1,2 e 3) evidenciou-se um emissor (aluno/autor) e um receptor da mensagem (leitor), que se comunica segundo Moscovici (2015) com um propósito em relação ao outro. Sendo essa uma abordagem dialógica conforme as afirmações de Ivana Marková (2006).

Em relação aos verbos selecionados (começou e passou), observou-se que apresentam uma ação no passado com indícios de que já está concluída. Desse modo, as memórias apresentadas nos textos são as memórias narradas pelo morador antigo, das quais o aluno se apropriou e refere-se a elas como suas, apresentando, portanto, suas escolhas.

O aluno/autor representa o lugar onde vive pela perspectiva do morador antigo, escreve sobre o passado do outro. Do ponto de vista da linguagem é uma construção ativa em que o sujeito fez escolhas e de acordo com Moscovici (2015) "[...] reflete uma comunicação passada de geração em geração". Desse modo, as escolhas feitas pelo aluno/autor refletem interações sociais vividas por ele e por meio das quais vai se constituindo enquanto ser humano e, portanto, construindo sua subjetividade.

Os resultados permitiram observar que, o aluno/autor traz elementos do passado do outro (cultura local), valorização dos sentimentos da época e descrição do tempo para falar do lugar onde vive. Essas priorizações e escolhas do sujeito por elementos do passado revelam as representações construídas sobre o lugar onde o aluno vive e sobre o outro.

De um modo geral, observa-se que na classe 1 , as palavras representam a vida e a cidade (do sujeito), as transformações do lugar, comparando presente e passado. $O$ presente é evidenciado pela voz do aluno/autor (sujeito) e o passado pela voz do entrevistado (o outro). O passado ao ser relatado traz o reviver, a lembrança, história e a cultura.

Em relação a classe 2, representa o espaço (cenário) onde acontecem as memórias, sendo o lugar em que aparecem os elementos da natureza (tranquilidade, brincadeiras, festejos religiosos) e o tempo, que é adjetivado como inesquecível. 
Outro elemento destacado no cenário é a cana de açúcar, que caracteriza um tipo de trabalho (corte de cana). Além disso, há sentimentos destacados como sonhos e magia, mas também o sentimento de destruição.

$\mathrm{Na}$ classe 3, apresenta-se os elementos que representam o trabalho do outro (plantação) e uma rotina (hora, trabalho, escola).

A escola tem destaque, entretanto, fica destacado no corpus que somente algumas pessoas tinham acesso a ela. Também está associada ao milho como um castigo dado pelos professores, o que marca a violência presente no contexto.

Há, também, um sentimento de valorização do trabalho representado pelo tipo de trabalho executado, das relações familiares (regras e condutas da família/casa) e das relações entre a comunidade local.

Segundo Moscovici a "[...] comunicação transmite emoções e significados semânticos" (MARKOVÁ, 2006, p. 274), neste caso, não são as vivências do sujeito, mas do outro, porque o aluno/autor assumiu as memórias do outro. O sujeito faz suas escolhas baseando-se nas emoções e significados transmitidos pelo outro, mas que de certa forma estão no senso comum e constituem sua consciência social.

O desenvolvimento do gênero Memórias Literárias perpassa pelos mecanismos linguísticos sob a vertente do ISD, o que evidencia nesse estudo o uso da linguagem e da língua, que leva em conta a situação de produção do texto: O que dizer? Como? Para quem? Com que intenção?

O meio de circulação do texto produzido, no caso do estudo, foi publicado em uma coletânea impressa e também online e pode circular em outras esferas além da escola e da comunidade local.

Pode-se afirmar que, a produção textual leva em conta o "agir linguageiro ou sua semiotização" no quadro do interacionismo sociodiscursivo, bem como, o gênero textual perpassa pelos mecanismos linguísticos para expressar as representações sociais do sujeito, que assume o personagem, a fala no lugar do outro, mas traz em seu discurso marcas de sua constituição enquanto sujeito social.

O texto é a própria materialização da ação de linguagem construída por determinadas operações que já existem historicamente no ambiente sociossemiótico, e o ser humano, no seu desenvolvimento, no decorrer da história, apropria-se delas. Para tanto, é um sujeito que age no mundo ativamente, que se constrói e é construído no contexto ou na interação social, por meio da produção de sistemas simbólicos e sociais na construção da realidade. 
As representações sociais identificadas no corpus são de um Brasil rural, distante da infância de quem o está retratando/vivendo. Parece oportuno afirmar que a realização de entrevistas com outros moradores, seriam fontes para reflexão do aluno sobre qual é o seu papel na construção da cidade.

Assim, ao finalizar o estudo, para que haja a oportunidade do discenso por meio do conflito de ideias, recomenda-se a realização de entrevistas com outros moradores do lugar, não apenas um único, no decorrer do trabalho em sala de aula, com a mediação do professor de Língua Portuguesa. Pois, ao refletir sobre as memórias de vários outros, o sujeito pode fazer a escolha de qual delas assumirá como sua, observando as percepções, emoções e sentimentos de diferentes indivíduos a respeito do lugar onde vivem. É uma forma de a escola contribuir para a construção do sujeito (subjetividade).

\section{REFERÊNCIAS}

BRONCKART, Jean Paul. Interacionismo Sócio-discursivo: uma entrevista com Jean Paul Bronckart. Revista Virtual de Estudos da Linguagem - ReVEL, São Paulo, v. 4, n. 6, mar. 2006. Tradução de Cassiano Ricardo Haag e Gabriel de Ávila Othero.

CAMARGO, Brigido V.. ALCESTE: um programa informático de análise quantitativa de dados textuais. In: MOREIRA, Antonia S.P.; CAMARGO, B. V.; JESUÍNO, JOSÉ C.; NÓBREGA, Sheva (organizadores). Perspectivas teórico-metodológicas em representações sociais. 1 ed. João Pessoa: Editora Universitária, 2005. p. 511-539.

CLARA, Regina A.; ALTENFELDER, Anna H.; ALMEIDA, Neide. Se bem me lembro... Caderno do Professor: Orientação para produção de textos. São Paulo: Cenpec, 2010. (Coleção Olimpíada).

DOLZ, Joaquim.; SCHNEUWLY, Bernard. Gêneros Orais e escritos na escola. Tradução e organização de Roxane Rojo e Glaís Sales Cordeiro. Campinas: Mercado de Letras, 2011.

MACHADO, Anna Rachel. Entrevista com Jean-Paul Bronckart. D.E.L.T.A., São Paulo, v. 20, n. 2, dez. 2004.

MACHADO, Anna Rachel; LOUSADA, Eliane Gouvêa. A apropriação de gêneros textuais pelo professor: em direção ao desenvolvimento pessoal e à evolução do "métier". Linguagem em (Dis)curso, Santa Catarina, v. 10, n. 3, dez. 2010. 
MARKOVÁ, Ivana. Dialogicidade e Representações Sociais. Tradução de Hélio Magri Filho. Rio de Janeiro: Vozes, 2006.

MARKOVÁ, Ivana. Ética na Teoria das Representações Sociais. In: JESUÍNO, Jorge Correia; MENDES, Felismina R. P.; LOPES, Manuel José. As Representações Sociais nas Sociedades em Mudança. Rio de Janeiro: Vozes, 2015, p. 80-98.

MOSCOVICI, Serge. Representações Sociais: investigações em psicologia social. Editado em inglês por Gerard Duveen; traduzido do inglês por Pedrinho A. Guareschi.11. ed. Rio de Janeiro: Vozes, 2015.

SÁ, Celso Pereira. Estudos de psicologia social: história, comportamento, representações e memória. Rio de Janeiro: EdUERJ, 2015. 